\title{
Recovery Ability of Dairy Buffalo Productivity after Treatment against Lice Infestation
}

\author{
Solouma, G.M.A. ${ }^{1}$, Abd El-Aleem. S.S. Desoky ${ }^{2}$, M.Y. Elaref ${ }^{1, *}$ \\ ${ }^{1}$ Department of Animal Production, Faculty of Agriculture, Sohag University- Egypt \\ ${ }^{2}$ Department of Plant Protections (Agric. Zoology), Faculty of Agriculture, Sohag University, Egypt
}

\begin{abstract}
The current study was carried out to determine the impact of sucking lice (Haematopinus tubercultus.) infestation on dairy buffalo cows productivity. Twenty four dairy buffalo cows were examined for lice infestation at the Experimental Animal Farm, Faculty of Agriculture, Sohag University, El-Kawamel city, Egypt. Animals were divided into two groups according to infection (14 uninfected animals and10 infected animals). Individual milk yield and body weight for all buffalo cows were weekly recorded for 8 weeks (3 weeks before infestation, 2 weeks during treatment and 3 weeks after treatment). Infected animals were treated with Butox 5\% EC at concentration of $2 \mathrm{ml}$ liter. The obtained results showed that the milk yield and body weight of infected animals were significantly $(P<0.05)$ decreased during infection and treatment stage than the corresponding value before infection (2.73 vs. $3.97 \mathrm{~L}$ and $523.8 \mathrm{vs} .535 .4 \mathrm{~kg}$, respectively).Also, these findings indicated that the infected animals were loss 31.18 and $2.17 \%$ of milk yield and body weight, respectively. So, farmer should pay attention to improve the ability of immune resistance against ectoparasites and implement a preventive program against ectoparasites which would harmful for dairy buffalo cows productivity, welfare and appearance.
\end{abstract}

Keywords: Dairy buffalo - Sucking lice - Productivity - Milk yield - Body weight

\section{INTRODUCTION}

Buffalo (Bubalus bubalis) play an important role in the livestock economy of several countries including Brazil, India, China, Pakistan, Turkey, and Italy, (Zicarelli, 2004). Buffalo population in the world is about 193 million head which consider the major source of milk production contributing $13.3 \%$ in World, $33.9 \%$ in Asia and $44.3 \%$ in Egypt total milk production. In addition, buffalo contributes $1.2,2.53$ and $18.86 \%$ of the total meat in these countries, respectively, which is a byproduct of buffalo farming in the aforementioned regions (FAO, 2013). The findings of El-Khadrawy et al. (2008) stated that buffaloes are the main source for good quality meat and milk in Egypt, despite this species is mostly reared under harsh socioeconomic conditions and has low productive and reproductive potentials.

Ectoparasites including lice, ticks, mites etc. play an important role in the transmission of certain pathogens (Loomis, 1986). It has been observed that ectoparasites do not only have direct effects on their host, they may also transmit pathogens, thereby acting as vectors of diseases (Parola et al. 2001). Importantly, some ectoparasites act as vectors for protozoa, bacteria, viruses and helminthes (Rehbein et al. 2003).

Buffalo are affected by a range of ectoparasites which can cause significant productivity losses and severely compromised animal welfare. The ectoparasites are known to cause heavy economic losses to livestock industry due to their usual habit of blood sucking, which cause adversely affects on the economic production (Fujusaki et al. 1993; Branscheid and Schroer, 1997). So, ectoparasites even in relatively little number induced negative effects on the welfare and productivity of livestock. Economic losses due to ectoparasitism are mainly due to loss in milk and beef production (Milne $\boldsymbol{e t}$ al. 2007), as well as due to inferior ovarian activity (El-Khadrawy et al. 2008). Control of buffalo parasitic infections is crucial to prevent economic losses (Veneziano et al. 2007).

Also, lice infestations contributes to huge economic losses due to skin and hide damage (Tancouse, 1986) in the form of light flecks and spots followed by secondary bacterial infection or scratching behaviour and inflammation of the skin (Webster and Bugby, 1990; Nafstad and Gronstol, 2001). 
Lice infested animals keep poor physical condition and develop an unthrifty, anemic appearance and discolored greasy hair (Nelson, 1984).Lice free animals are more profitable than infested animals due to increased rate of weight gain and more feed utilization(Kettle, 1974).Reporting of disease or disease causing pathogen is very important for planning control measure strategies to minimize economic and production losses associated with pathogen and disease they cause (Shamim $\boldsymbol{e t}$ al. 2015). The results of Hossain et al. (2016) and Regasa et al. (2015) recommended that very good veterinary services and management practice should be put in place to avoid the negative impact of ectoparasites infestations on animal productivity. This study was aimed to determine the impact of lice infestation on the dairy buffalo cows productivity and possibility of recovery production level before lice infestation.

\section{MATERIALS AND METHODS}

\subsection{Experimental Design}

The present study was carried out in the Experimental Animal Farm, Faculty of Agriculture, Sohag University, El-Kawamel city, Egypt. A total of 24dairy buffalo cows were used at $2^{\text {nd }}$ parity and in mid-lactation with $566.8 \mathrm{~kg}$ average body weight at the beginning of trial.

All animals were divided into two groups according to infection (14 uninfected animals and10 infected animals). Infected animals were treated with Butox 5\% EC at concentration of $2 \mathrm{ml} / \mathrm{liter}$. The active ingredient in Butox is Deltamethrin which belongs to the class of synthetic pyrethroids which resemble natural pyrethrins found in the pyrethrum plant. Natural pyrethrins are unstable and rapidly degrade in contact with water, air and light. Deltamethrin's effect on the parasite is mainly through contact and ingestion. Individual milk yield (liter) and body weight $(\mathrm{kg})$ of buffalo cows were recorded once weekly for 8 successive weeks ( 3 weeks before infestation, 2 weeks during treatment and 3 weeks after treatment).

\subsection{Statistical Analysis}

Data were analyzed by the PROC MIXED for repeated measurements of SAS (SAS 9.3, SAS Inst. Inc., Cary, NC) and the results presented as Least Squares Means (LSM). The statistical mixed model included the fixed effects of treatment (infected and uninfected), time (weeks, 1 to 8), the random effect of the animal, the interactions (treatment with time) and the residual error.

\section{RESULTS AND DISCUSSIONS}

Data presented in Table 1 showed that weekly milk yield and body weight of uninfected animals were not affected. In spite of, there were a normal slightly decrease in milk yield and increase in body weight during later weeks. On the other hand, infected animals were significantly $(\mathrm{P}<0.05)$ decreased milk yield and body weight during infection and treatment stagethan before infection (2.73 vs. 3.97 Land 523.8 vs. $535.4 \mathrm{~kg}$, respectively). These results are in agreement with those of Berriatua $\boldsymbol{e t}$ al. (2001) showed that ectoparasites is one of the most important factors that hinder the productive efficiency of farm animals, as it causes hypersensitivity, marked blood loss, secondary infestation, excoriation and ultimately death in few cases. Also, they concluded that the ectoparasites cause indirect harm, particularly when present at high intensities, causing disturbance, increasing levels of behavior such as rubbing and reduced time spent for grazing or ruminating and in some cases, self-wounding.

The figures 1 and 2 illustrated that infected animals loss $31.18 \%$ in milk yield and $2.17 \%$ inbody weight during infection and treatment stage. These findings agree with those of Gibney et al. (1985) and Loomis, (1986), they found that lice infestation caused loss body weight up to 25-30 kg as well as decrease milk yield by $15-25 \%$ per animal /year. Losses in milk yield and body weight during infection and treatment stage could be attributed to lice consumption of host blood and decrease the available nutrients for production. These results are agree with those of Branscheid and Schroer, (1997), they found that lice cause heavy economic losses to livestock industry due to their usual habit of blood sucking, which adversely affects the economic production. Also, the obtained findings showed that the animals after treatment against lice with Butox 5\% EC at concentration of $2 \mathrm{ml} /$ liter were recovered about $34.77 \%$ in total milk yield and $91.38 \%$ in body weight from their productivity before infection. 
From these results it is clear that the animals which have lower milk yield and body weight were more likely to lice infestation than those with higher milk yield and body weight (3.97 L and $535.4 \mathrm{~kg}$ vs. $5.45 \mathrm{~L}$ and $594 \mathrm{~kg}$ ), respectively. These results are in agreement with those of Tilkiet al. (2015) showed that cattle of poor and medium body condition were more likely to be infested by ectoparasites compared to cattle of good body condition. The decrease in milk yield and body weight for infected animals may be attributed to the decrease in the nutrition levels, which reflected in the decline of their immune ability to resist lice infection. However, contrasting findings has been reported by Onu and Shiferaw (2013) and Nigatu and Teshome (2012) where there was no significant variation in the prevalence among body condition scores. These variations could be due to husbandry practices differences of this and previous studies.

\section{Conclusion}

Finally, from these results could be concluded that the productivity of infected animals was decreased due to lice infestation, which can recover it after treatment with Butox 5\% EC at concentration of 2 $\mathrm{ml} /$ liter.

\section{RECOMMENDATION}

Generally, from our results we can recommended that the farmers should pay attention to good and balanced nutrition for animals to improve their immune resistance ability against ectoparasites and implement a preventive program against ectoparasites which would harmful for dairy buffalo cows productivity, welfare and appearance.

Table1. Effect of sucking lice (Haematopinus tubercultus) on dairy buffalo cows productivity

\begin{tabular}{|c|c|c|c|c|c|c|c|c|c|}
\hline & \multicolumn{3}{|c|}{ Before infection } & \multicolumn{2}{|c|}{$\begin{array}{c}\text { Infection and } \\
\text { Treatment stage }\end{array}$} & \multicolumn{3}{|c|}{ After treatment } \\
\hline & & W1 & W2 & W3 & W4 & W5 & W6 & W7 & W8 \\
\hline \multirow{2}{*}{ 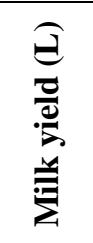 } & $\begin{array}{l}\text { Uninfected } \\
\text { animal }\end{array}$ & $\begin{array}{c}5.50 \\
\pm \\
0.06\end{array}$ & $\begin{array}{c}5.43 \\
\pm \\
0.06\end{array}$ & $\begin{array}{c}5.41 \\
\pm \\
0.07\end{array}$ & $\begin{array}{c}5.34 \\
\pm \\
0.07\end{array}$ & $\begin{array}{c}5.34 \\
\pm \\
0.06\end{array}$ & $\begin{array}{c}5.23 \\
\pm \\
0.06\end{array}$ & $\begin{array}{c}5.14 \\
\pm \\
0.06\end{array}$ & $\begin{array}{c}5.09 \\
\pm \\
0.06\end{array}$ \\
\hline & $\begin{array}{l}\text { Infected } \\
\text { animal } \\
(\mathbf{n}=\mathbf{1 0})\end{array}$ & $\begin{array}{c}4.02^{\mathrm{a}} \\
\pm \\
0.04\end{array}$ & $\begin{array}{c}3.96^{\mathrm{a}} \\
\pm \\
0.05\end{array}$ & $\begin{array}{c}3.92^{\mathrm{a}} \\
\pm \\
0.04\end{array}$ & $\begin{array}{c}2.82^{c} \\
\pm \\
0.04\end{array}$ & $\begin{array}{c}2.64^{\mathrm{c}} \\
\pm \\
0.03\end{array}$ & $\begin{array}{c}3.04^{b} \\
\pm \\
0.04\end{array}$ & $\begin{array}{c}3.12^{b} \\
\pm \\
0.04\end{array}$ & $\begin{array}{c}3.32^{\mathrm{b}} \\
\pm \\
0.04\end{array}$ \\
\hline \multirow{2}{*}{ 긍 } & $\begin{array}{l}\text { Uninfected } \\
\text { animal } \\
(n=14)\end{array}$ & $\begin{array}{c}592.1 \\
\pm \\
2.06\end{array}$ & $\begin{array}{c}594.3 \\
\pm \\
2.10\end{array}$ & $\begin{array}{c}595.7 \\
\pm \\
2.19\end{array}$ & $\begin{array}{c}599.7 \\
\pm \\
2.20\end{array}$ & $\begin{array}{c}601.4 \\
\pm \\
2.12\end{array}$ & $\begin{array}{c}604.3 \\
\pm \\
2.19\end{array}$ & $\begin{array}{c}607.9 \\
\pm \\
2.14\end{array}$ & $\begin{array}{c}609.7 \\
\pm \\
2.11\end{array}$ \\
\hline & $\begin{array}{l}\text { Infected } \\
\text { animal } \\
(\mathbf{n}=\mathbf{1 0})\end{array}$ & $\begin{array}{c}531.4^{\mathrm{a}} \\
\pm \\
1.72\end{array}$ & $\begin{array}{c}535.6^{\mathrm{a}} \\
\pm \\
1.79\end{array}$ & $\begin{array}{c}539.2^{\mathrm{a}} \\
\pm \\
1.80\end{array}$ & $\begin{array}{c}527.4^{\mathrm{ab}} \\
\pm \\
1.52\end{array}$ & $\begin{array}{c}520.2^{\mathrm{b}} \\
\pm \\
1.35\end{array}$ & $\begin{array}{c}527.4^{\mathrm{ab}} \\
\pm \\
1.43\end{array}$ & $\begin{array}{c}535.2^{\mathrm{a}} \\
\pm \\
1.70\end{array}$ & $\begin{array}{c}540.6^{\mathrm{a}} \\
\pm \\
1.62\end{array}$ \\
\hline
\end{tabular}

Data are least square means and standard error of the mean.

${ }^{a, b, c}$ Meanswith different superscriptswithin the same roware different $(P<0.05)$.

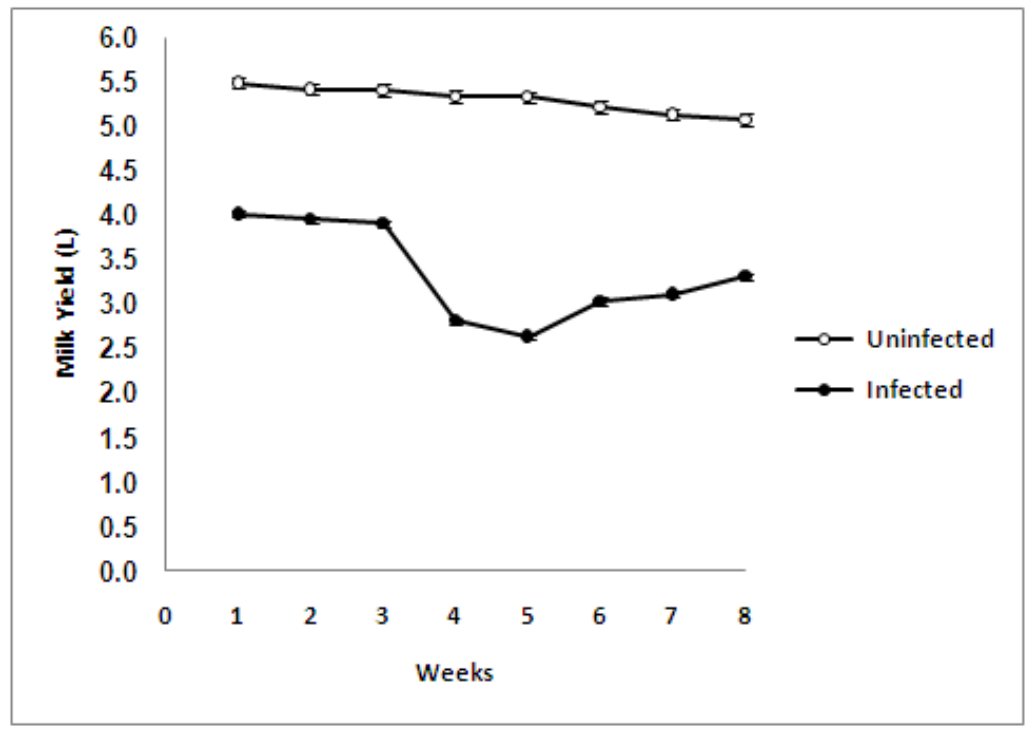

Fig1. Effect of sucking lice on daily milk yield of dairy buffalo cows 


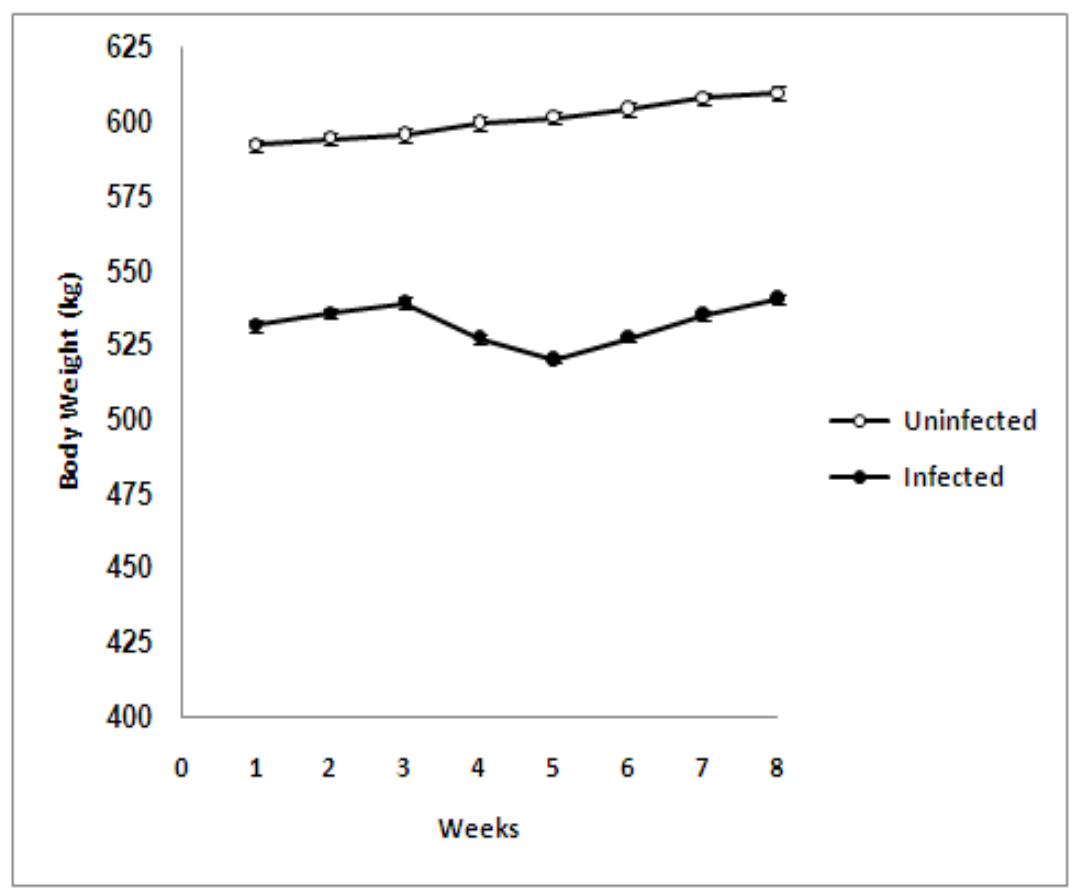

Fig2. Effect of sucking lice on body weight of dairy buffalo cows

\section{Author's Contribution}

G.M.A. conceived and designed the study, A.S.S. executed the experiment and M.Y. analyzed the data. All authors interpreted the data, critically revised the manuscript for important intellectual contents and approved the final version.

\section{REFERENCES}

Berriatua E, French NP, Broster CE, Morgan KL and Wall R, 2001. Effect of infestation with Psoroptes ovis on the nocturnal rubbing and lying behaviour of housed sheep.Applied Animal Behaviour Science, 71: 43-55.

Branscheid W and Schroer, 1997. Damage to cattle hides, detection, frequency and economic importance. Fleischwirtschaft., 77: 333-37.

El-Khadrawy H, Elmaghazy F, Abdel Aziz M and Ahmed W, 2008.Field investigation on the correlation between ovarian activity and fasciolios is in buffalo-cows. American-Euroasian Journal of Agriculture and Environmental Science, 3: 539-546.

FAO, 2013.Livestockdatabase.http://faostat3.fao.org/browse/Q/QL/E. Accessed 20 June 2016

FujusakiK, Kamio T, Kawazn S, Shimizu S and Shimura K, 1993.Theleria sergenti experimental transmission by the long nosed cattle louse, Linognathus vituli. Ann. Trop. Med. Parasitol., 87: 217-18.

Gibney VJ, Campbell JB, Boxler DJ, Clanton DC and Deutscher GH, 1985. Effects of various infestation levels of cattle lice (Mallophaga: Trichodectidae: and Anoplura: Haematopinidae) on feed efficiency and weight gains of beef heifers. J. Econ. Entomol., 78: 1304-07.

Hossain M, Bhuiyan MJU, Digonto MTHI, (2016). Epidemiology of ecto-parasitic infestation of cattle in milk shed areas of Baghabari of Shahjadpur Upazila of Sirajgonj district, Bangladesh. J. Adv. Parasitol. 3(2): 56-60.

Kettle PR, 1974 .The influence of cattle lice, Damalinia bovis and Linognathus vituli on weight gain in beef animals. New Zealand Vet. J.,22: 10-11.

Loomis EC, 1986. Ectoparasites of cattle. Vet. Clin. North America, 2: 299-321.

Milne C, Dalton G and Stott A, 2007. Integrated control strategies for ectoparasites in Scottish sheep flocks. Livestock Science, 106: 243-253.

Nafstad O and Gronstol H, 2001. The effect of eradication of lice on the occurrence of the grain defect light flecks and spots on cattle hides. Acta. Vet. Scand.,42: 99-106.

Nelson WA, 1984. Effects of nutritionon animals on their ectoparasites. J. Med. Entomol.,21: 621-35. 
Nigatu K and Teshome F, 2012.Population dynamics of cattle ectoparasite in Western Amhara National Regional State, Ethiopia. Journal of Veterinary Medicine and Animal Health 4(1): 2226.

Onu SH and Shiferaw TZ, 2013.Prevalence of ectoparasite infestations of cattle in Bench Maji Zone, Southwest Ethiopia. Veterinary World 6(6): 291-294.

Parola P, Inukoma H, Camicas JL, Bronqui P and Raoult D, 2001. Detection and identification of spotted fever group Rickettiae and Ehrlichae in Africa ticks. Emerging Infectious Diseases. 7(6): 1014-1017.

Regasa TD, Tsegay AK and Waktole H, 2015.Prevalence of major ectoparasites of calves and associated risk factors in and around Bishoftu town. Afr. J. Agric. Res. 10(10):1127-1135.

Rehbein S, Visser M, Winter R, Trommer B, Matthes HF, Maciel SE and Marley E, 2003. Productivity effects of bovine mange and control with ivermectin. Veterinary Parasitology, 114: 267-284.

ShamimA, Mushtaq A and Hassan M, 2015.No record of lice (Pthiraptera) distribution and abundance in traditionally managed Buffalo and Cattle in Rawalakot Azad Kashmir Pakistan. Journal of Entomology and Zoology Studies; 3(3): 416-418.

Tancouse JJ, 1986. Skin, hide and leather defects. Tanners' Council Research Laboratory, Cincinnati, Ohio, USA.

Tilki T, Eshetu A and Waktola H, 2015. Major ectoparasites of cattle in Ada'a district, East Showa Zone, Ethiopia. Livestock Research for Rural Development 27 (10)Article 198. Retrieved July 25, 2016, from http://www.Irrd.org/lrrd27/10/eshe27198.htm

Veneziano V, Santaniello M, Carbone S, Pennacchio S, Morgoglione ME, Schioppi M, Condoleo R and Cringoli G, 2007. Lice (Haematopinus tuberculatus) in water buffalo farms from central Italy. Ital J Anim Sci 6:926-927.

Webster RM and Bugby A, 1990. Lightspot and fleck grain defects of economic importance to the UK leather industry, Part I Identification of causal agent. British Leather Confedration Report, LR-184, P. 22.

Zicarelli L, 2004. Buffalo milk: its properties, dairy yield and mozzarella production. Vet. Res. Communications 28:127-135 